\title{
REPUTASI AUDITOR DAN KARAKTERISTIK PERUSAHAAN TERHADAP MANAJEMEN LABA
}

\author{
DEWI KURNIA INDRASTUTI \\ VENIA MARIA DJOJO \\ Trisakti School of Management, Jl. Kyai Tapa No. 20, Grogol, Jakarta Barat, Indonesia \\ dewiindrastuti@gmail.com
}

\begin{abstract}
The purpose of this study is to analyze the impact of public accountant firm size, auditor specialization, company size, operating cash flow, leverage, return on assets, market to book value ratio, independent commissioners and firm age on earnings management. Purposive sampling method is used to obtain samples from manufacturing companies that listed in Indonesian Stock Exchange during 2015-2018. There are 71 companies meet the criteria and the hypothesis was tested using multiple linear regression analysis. The results indicate that company size, operating cash flow, leverage and return on assets have a significant effect on earnings management. Other independent variables such as public accountant firm size, auditor specialization, market to book value ratio, independent commissioners and firm age have no influence on earnings management.
\end{abstract}

Keywords: Company size, operating cash flow, leverage, return on asset, earning management

\begin{abstract}
Abstrak: Tujuan dari penelitian ini adalah untuk menganalisis pengaruh ukuran Kantor Akuntan Publik spesialiasi auditor, ukuran perusahaan, aliran kas operasi, leverage, return on asset, market to book value ratio, dewan komisaris independen dan umur perusahaan terhadap manajemen laba. Teknik pemilihan sampel adalah dengan metode purposive sampling yang digunakan untuk mendapatkan sample dari perusahaan manufaktur yang terdaftar di Bursa Efek Indonesia selama 20152018. Terdapat 71 perusahaan yang memenuhi kriteria dan dianalisa dengan analisis regresi linier berganda. Hasil penelitian ini menunjukkan bahwa ukuran perusahaan, aliran kas operasi, leverage dan return on asset berpengaruh signifikan terhadap manajemen laba. Variabel independen lainnya seperti ukuran auditor, spesialisasi auditor, market to book value ratio, dewan komisaris independen dan umur perusahaan tidak memiliki pengaruh terhadap manajemen laba.
\end{abstract}

Kata kunci: Ukuran perusahaan, aliran kas operasi, leverage, return on asset, manajemen laba

\section{PENDAHULUAN}

Pemangku kepentingan memerlukan informasi yang akurat dalam bentuk pelaporan keuangan formal yang menjelaskan mengenai kinerja dan keuangan perusahaan yang akan digunakan sebagai sumber informasi untuk pengambilan keputusan ekonomi dan evaluasi atas kinerja. Manajemen memiliki kewajiban untuk mempertanggungjawabkan kinerjanya melalui Laporan Keuangan. Salah satu indikator penting dalam laporan keuangan adalah laba karena laba mencerminkan tingkat pengembalian investasi, risiko dan memberikan gambaran pertumbuhan perusahaan dimasa datang. Informasi laba bermanfaat untuk pihak internal yaitu perusahaan dan pihak eksternal antara lain kreditor, dan investor. Tekanan untuk mencapai laba dalam jumlah tertentu dapat 
membuat manajemen melakukan manajemen laba yaitu upaya manajer perusahaan untuk mempercantik laporan keuangan dengan mengendalikan tingkat laba yang disajikan dalam laporan keuangan untuk mengelabui pihak-pihak yang ingin mengetahui kinerja dan kondisi perusahaan. Manajemen laba disebabkan oleh ketidakselarasan kepentingan antara manajer dan pemilik perusahaan dan karena informasi yang tidak berimbang antara pihak manajemen dan pemegang saham (Christiani dan Nugrahanti 2014). Informasi yang dimiliki pemegang saham dianggap lebih sedikit daripada pihak manajemen karena pihak manajemen mengetahui kondisi perusahaan yang sebenarnya karena berhubungan langsung dengan pengelolaan perusahaan. Masalah manajemen laba tidak hanya terjadi di negara berkembang tetapi juga di negara maju antara lain kasus Enron dan WorldCom.

Penelitian ini dikembangkan dari penelitian Ahmad et al. (2016). Perbedaannya adalah variabel ukuran perusahaan, aliran kas operasi, leverage yang semula adalah variabel kontrol menjadi variabel independen pada penelitian ini dan empat variabel independen baru ditambahkan yaitu return on asset dan market to book value ratio ditambahkan berdasarkan Yuliana dan Trisnawati (2015) dan dewan komisaris independen ditambahkan berdasarkan Wimelda dan Chandra (2018) serta umur perusahaan ditambahkan berdasarkan penelitian Yunietha dan Palupi (2017). Tujuan penelitian ini adalah memperoleh bukti empiris pengaruh reputasi auditor dan karakteristik perusahaan terhadap manajemen laba.

\section{Teori Keagenan}

Jensen dan Meckling menjelaskan mengenai hubungan antara agen dan principal yaitu principal adalah pemilik sumber daya ekonomis yaitu pemegang saham dan agen adalah pihak yang mengelola penggunaan dan pengendalian sumber daya yaitu manajer. Principal ingin mengetahui informasi terkait kegiatan operasional perusahaan dan penggunaan dana dalam perusahaan tetapi karena agen memiliki keinginan untuk memaksimalkan keuntungan pribadi membuat agen terkadang tidak bertindak sesuai dengan yang diharapkan principal.

Hubungan keagenan selain dapat menyebabkan konflik kepentingan juga dapat mengakibatkan asimetri informasi yaitu pihak manajemen dianggap memiliki banyak informasi dibandingkan pemegang saham. Hal ini disebabkan karena pihak manajemen mengelola perusahaan sehingga mengetahui kondisi perusahaan yang sebenarnya dan dikhawatirkan manajemen hanya memberikan informasi yang memperkuat posisi dan kepentingannya sedangkan pemegang saham memiliki informasi yang terbatas. Auditor independen diharapkan dapat meminimalkan tindakan karena sebagai pihak ketiga yang independen dapat menyelaraskan kepentingan antara kedua pihak tersebut. (Yuliana dan Trisnawati 2015).

\section{Manajemen Laba}

Manajemen laba terjadi ketika manajer menggunakan pertimbangan dalam pelaporan keuangan dan dalam pengaturan transaksi dengan tujuan mengubah laporan keuangan untuk menyesatkan beberapa pemangku kepentingan mengenai kinerja ekonomi yang mendasari perusahaan atau untuk mempengaruhi hasil kontrak yang bergantung pada data akuntansi yang dilaporkan pada laporan. (Healy dan Wahlen 1999).

Menurut Christiani dan Nugrahanti (2014) manajemen laba merupakan dampak dari agency problem yaitu ketidakselarasan kepentingan antara manajer dan pemilik perusahaan yang muncul karena adanya asimetri informasi, yang berarti adanya 
informasi yang didapat manajemen dan tidak seimbang dengan yang didapatkan oleh pihak eksternal. Sehingga adanya salah satu pihak yang lebih banyak memiliki informasi.

Manajemen laba memiliki empat pola dasar menurut Scott (2015), yaitu taking a bath, income minimization, income maximization, dan income smoothing. Pola pertama, taking a bath adalah kegiatan melaporkan rugi yang besar pada periode berjalan dengan mengakui beban pada periode yang akan datang dan menyembunyikan bukti yang ada, sehingga laba yang di laporkan diperiode yang akan datang akan mengalami peningkatan meskipun tidak dalam kondisi menguntungkan. Pola yang kedua, income minimization adalah kegiatan yang dilakukan manajemen dengan mengurangi laba pada periode berjalan dari laba sesungguhnya. Sehingga apabila pada periode mendatang perusahaan memiliki laba yang rendah, manajemen bisa mengatasinya dengan mengambil laba dari periode sebelumnya. Pola yang ketiga, income maximization adalah tindakan yang dilakukan manajemen dengan mengakui beban pada periode berjalan pada laporan periode selanjutnya. Pola ini dilakukan untuk menghindari pelanggaran kontrak hutang jangka panjang. Pola yang keempat adalah income smoothing yaitu tindakan meratakan laba yang dilaporkan untuk tujuan pelaporan eksternal, terutama investor karena umumnya investor menyukai laba yang relatif stabil dan konsisten.

\section{Ukuran Kantor Akuntan Publik}

Ukuran kantor akuntan publik merupakan salah satu alat ukur untuk mengetahui kualitas audit yang akan dihasilkan oleh seorang auditor. Semakin besar ukuran kantor akuntan publik dianggap mempunyai keahlian, pengalaman dan reputasi yang lebih baik sehingga dapat membatasi terjadinya manajemen laba.
Keahlian didapat melalui pendidikan, pelatihan dan pengalaman dalam bidang akuntansi dan auditing serta kemampuan untuk menilai secara objektif sesuai dengan prinsip akuntansi. Amijaya dan Prastiwi (2013) menyatakan adanya pengaruh negatif antara ukuran kantor akuntan publik dan manajemen laba. Hal ini menunjukkan bahwa perusahaan yang diaudit oleh auditor di KAP big four mampu membatasi tindakan manajemen laba. Hasil penelitian ini didukung oleh penelitian yang dilakukan Gerayli et al., (2011), Ahmad et al., (2016), Kurniawansyah, (2016), Atiqah dan Purwanto, (2011) menyatakan bahwa ukuran kantor akuntan publik berpengaruh positif terhadap manajemen laba. Hal ini menunjukkan bahwa perusahaan yang diaudit oleh KAP big four dapat meningkatkan manajemen laba. Yuliana dan Trisnawati (2015) menyatakan bahwa ukuran kantor akuntan publik tidak berpengaruh terhadap manajemen laba. Hal ini menunjukkan bahwa ukuran kantor akuntan publik tidak dapat mempengaruhi tindakan manajemen laba yang dilakukan oleh perusahaan. Hasil penelitian tersebut didukung oleh penelitian yang dilakukan Napitupulu, (2012), Rachmawati dan Fuad, (2013), serta Alexander dan Hengky (2017). Hipotesis yang diajukan adalah:

$\mathrm{H}_{1}$ Ukuran Kantor Akuntan Publik berpengaruh terhadap manajemen laba.

\section{Spesialisasi Auditor}

Spesialisasi auditor dalam suatu industri ditentukan dengan melihat frekuensi penugasan yang dimiliki oleh KAP dalam pemeriksaan suatu perusahaan sejenis berdasarkan kelompok perusahaan yang ditetapkan Bursa Efek Indonesia. Selain penguasaan atas teknik audit dan ilmu akuntansi, auditor harus memahami jenis industri dan risiko klien. Pengalaman auditor akan membantu dalam mendeteksi kesalahan yang terjadi pada data kliennya sehingga 
dapat meminimalkan tindakan manajemen laba (Kurniawansyah 2016). Gerayli et al. (2011), Amijaya dan Prastiwi (2013), Ahmad et al., (2016), Kurniawansyah, (2016), serta (Christiani dan Nugrahanti, 2014) menyatakan spesialisasi auditor berpengaruh negatif terhadap manajemen laba yang artinya perusahaan yang diaudit oleh auditor yang memiliki spesialisasi industri cenderung tidak melakukan manajemen laba.

Pradhana dan Rudiawarni (2013) menyatakan bahwa spesialisasi auditor berpengaruh positif terhadap manajemen laba. Hal itu menunjukkan bahwa auditor spesialisasi industri bukan untuk mengurangi terjadinya manajemen laba melainkan untuk peningkatan kredibilitas laporan keuangan. Sedangkan menurut Yuliana dan Trisnawati (2015) spesialisasi auditor tidak berpengaruh terhadap manajemen laba, jadi siapapun auditornya peluang untuk melakukan melakukan manajemen laba tetap ada. Hipotesis yang diajukan adalah:

$\mathrm{H}_{2}$ Spesialisasi auditor berpengaruh terhadap manajemen laba.

\section{Ukuran Perusahaan}

Secara umum besaran ukuran perusahaan dapat dinilai dari besarnya aset milik perusahaan Yuliana dan Trisnawati (2015). Ukuran perusahaan yang besar, melibatkan lebih banyak pihak dalam pengelolaannya dan lebih berpengaruh terhadap persepsi publik dibandingkan dengan perusahaan kecil (Arifin dan Destriana 2016). Hasil penelitian Yuliana dan Trisnawati (2015), Rachmawati dan Fuad (2013), Agustia dan Suryani (2018), Susanto (2016), dan Kurniawansyah (2016) menyatakan bahwa ukuran perusahaan berpengaruh positif terhadap manajemen laba artinya semakin besar ukuran perusahaan menyebabkan perusahaan akan mempertahankan nama baik dengan cara melakukan manajemen laba untuk mempertahankan posisinya atau untuk menunjukkan kinerja perusahaan yang baik sesuai dengan yang diinginkan pihak perusahaan.

Susanto dan Yangrico (2020), Susanto, Pradipta, dan Cecilia (2019), Ahmad et al. (2016), Gerayli et al. (2011), serta Herlambang dan Darsono (2015) menyatakan terdapat pengaruh negatif ukuran perusahaan terhadap manajemen laba, artinya semakin besar ukuran perusahaan maka semakin kecil terjadinya tindakan manajemen laba. Christiani dan Nugrahanti (2014), Rachmawati dan Fuad, (2013), Yunietha dan Palupi, (2017), Alexander and Hengky, (2017) menyatakan bahwa ukuran perusahaan tidak berpengaruh terhadap tindakan manajemen laba. Hasil ini karena besar kecilnya total aset suatu perusahaan bukan merupakan pertimbangan satu-satunya bagi investor dalam mengambil keputusan investasi dan total aset tidak menjamin kinerja perusahaan akan baik. Hipotesis yang diajukan adalah:

$\mathrm{H}_{3}$ Ukuran perusahaan berpengaruh terhadap manajemen laba.

\section{Aliran Kas Operasi}

Aliran kas operasi yang dihasilkan suatu perusahaan menggambarkan kecukupan kegiatan operasional dalam melunasi pinjaman jangka pendek perusahaan dan bermanfaat untuk melihat kemampuan operasional perusahaan dan kemampuan perusahaan untuk membiayai pengeluaran dari kegiatan operasional perusahaan. Aliran kas operasi menurun membuat perusahaan cenderung menurunkan tindakan manajemen laba (Yuliana dan Trisnawati 2015). Hasil penelitian Yuliana dan Trisnawati (2015), Rachmawati dan Fuad, (2013) dan Christiani dan Nugrahanti (2014) adalah aliran kas operasi berpengaruh negatif terhadap manajemen laba. Hal ini dapat diartikan bahwa jika aliran kas operasi meningkat maka manajemen laba akan menurun. Aliran kas operasi yang kecil 
cenderung akan meningkatkan keinginan perusahaan untuk melakukan manajemen laba, sehingga perusahaan terlihat baik dimata para investor.

Menurut Gerayli et al. (2011) serta Amijaya dan Prastiwi (2013) aliran kas operasi berpengaruh positif terhadap manajemen laba. Artinya, tingginya aliran kas operasi yang dimiliki suatu perusahaan maka semakin tinggi peluang manajemen untuk melakukan manajemen laba. Sedangkan hasil penelitian dari Ahmad et al., (2016) menyatakan bahwa aliran kas operasi tidak berpengaruh terhadap manajemen laba. Hal ini menunjukkan peningkatan dan penurunan arus kas cenderung tidak mempengaruhi keinginan perusahaan untuk melakukan manajemen laba. Hipotesis yang diajukan adalah:

$\mathrm{H}_{4}$ Aliran kas operasi berpengaruh terhadap manajemen laba.

\section{Leverage}

Perusahaan yang memiliki rasio leverage tinggi berarti memiliki proporsi hutang lebih besar daripada proporsi asetnya dan cenderung melakukan manajemen laba. Ahmad et al., (2016) menyatakan bahwa ada pengaruh positif Leverage terhadap manajemen laba yang artinya adalah karena perusahaan cenderung lebih sulit mendapatkan tambahan modal jika rasio leverage perusahaan tinggi maka perusahaan cenderung melakukan manajemen laba untuk mempercantik laporan keuangan perusahaan. Penelitian ini didukung oleh hasil penelitian dari Gerayli et al. (2011), Kurniawansyah (2016), Agustia dan Suryani (2018), Susanto, Pirzada, dan Adrianne (2019), Susanto dan Yangrico (2020).

Yuliana dan Trisnawati (2015), Susanto (2013) menyatakan bahwa leverage berpengaruh negatif terhadap manajemen laba. Hal ini menunjukkan perusahaan melakukan manajemen laba agar kinerja perusahaan terlihat baik bagi para pengguna laporan keuangan dengan nilai utang yang rendah. Sedangkan hasil penelitian Rachmawati dan Fuad (2013) serta Alexander and Hengky, (2017) menyatakan bahwa tidak ada pengaruh antara leverage terhadap manajemen laba. Hipotesis yang diajukan adalah:

$\mathrm{H}_{5} \quad$ Leverage berpengaruh terhadap manajemen laba.

\section{Return on Asset}

Return on asset berfungsi untuk mengukur efektivitas perusahaan dalam menghasilkan laba melalui pengoperasian aset milik perusahaan. Susanto dan Yangrico (2020), Susanto, Pradipta, dan Cecilia (2019), serta Yuliana dan Trisnawati (2015) menyatakan bahwa return on asset perusahaan berpengaruh positif terhadap manajemen laba. Hal ini menunjukkan bahwa jika perusahaan memiliki kinerja yang buruk maka memicu manajer untuk menaikkan laba perusahaan dengan melakukan manajemen laba sehingga kinerja perusahaan terlihat baik. Hasil penelitian tersebut didukung oleh penelitian yang dilakukan oleh Kurniawansyah (2016), dan Alexander dan Hengky (2017).

Menurut Abbadi, Hijazi, and AlRahahleh (2016) dan Ngamchom (2015) Return on Asset memiliki pengaruh negatif terhadap manajemen laba. Hal ini menunjukkan perusahaan yang memiliki return on asset yang tinggi kurang memungkinkan melakukan manipulasi laba, karena perusahaan yang memanipulasi laba secara tidak langsung bermaksud memanipulasi pendapatan mereka agar perusahaan terlihat menarik sedangkan return on asset yang tinggi berarti perusahaan sedang dalam kondisi yang baik sehingga tidak melakukan manipulasi laba. Sedangkan menurut Nurdiniah and Herlina (2015) menyatakan bahwa tidak ada pengaruh return on asset terhadap manajemen laba. Hal ini menunjukkan bahwa kinerja dari perusahaan 
tidak mempengaruhi tindakan manajemen laba, karena penentuan bonus tidak dilihat dari nilai return on asset tetapi berdasarkan jumlah target bonus yang ditetapkan perusahaan. Hipotesis yang diajukan adalah: $\mathrm{H}_{6}$ Return on Asset berpengaruh terhadap manajemen laba.

\section{Market to Book Value Ratio}

Menurut Mohammad et al. (2016) perusahaan dengan market to book value ratio digunakan sebagai salah satu indikator untuk mengukur tingkat pertumbuhan perusahaan. Semakin tinggi market to book value ratio memiliki kecenderungan untuk terlibat dalam manajemen laba untuk memenuhi ekspektasi pasar. Dengan melakukan hal tersebut maka kinerja perusahaan akan terlihat baik di mata para investor. Almalita (2017) menyatakan bahwa market to book value ratio berpengaruh negatif terhadap manajemen laba. Hal ini menunjukkan bahwa perusahaan dapat melakukan manajemen laba dengan cara mempengaruhi performa harga saham perusahaan sehingga terlihat baik. Christiani dan Nugrahanti (2014) dan Gerayli et al. (2011), menyatakan bahwa market to book value ratio berpengaruh positif terhadap manajemen laba. Hal ini menunjukkan bahwa perusahaan akan mempertahankan proformanya dengan melakukan manajemen laba sehingga proforma perusahaan tetap terlihat baik dimata pihak yang memiliki kepentingan dengan perusahaan. Sedangkan menurut Yuliana dan Trisnawati (2015) market to book value ratio tidak berpengaruh terhadap manajemen laba. Hipotesis yang diajukan adalah:

$\mathrm{H}_{7}$ Market to Book Value Ratio berpengaruh terhadap manajemen laba.

\section{Dewan Komisaris Independen}

Anggota Dewan Komisaris yang tidak terafiliasi dengan Direksi, anggota Dewan Komisaris lainnya dan pemegang saham pengendali, dan tidak mempunyai hubungan bisnis atau apapun yang bisa berdampak pada independensinya adalah Dewan Komisaris Independen. Hal ini akan membuat iklim yang lebih setara (fair), independen, dan obyektif sehingga bisa memperhatikan kepentingan pemegang saham termasuk pemegang saham minoritas dan pemangku kepentingan lainnya.(Subrata 2020).

Hasil penelitian Arifin dan Destriana (2016) dan Susanto (2016) menunjukkan bahwa dewan komisaris independen berpengaruh positif terhadap manajemen laba, ini artinya semakin banyak jumlah anggota dewan komisaris independen maka semakin besar kemungkinan terjadinya tindakan manajemen laba. Sedangkan menurut Herlambang dan Darsono (2015) dewan komisaris independen berpengaruh negatif terhadap manajemen laba. Artinya semakin banyak jumlah anggota dewan komisaris independen maka akan memperkecil kemungkinan terjadinya manajemen laba. Kehadiran dewan komisaris independen mampu memberikan kontribusi pengawasan untuk menghindari kecurangan.

Menurut Wimelda dan Chandra (2018) dewan komisaris independen tidak berpengaruh terhadap manajemen laba, artinya jumlah anggota dewan komisaris independen tidak berpengaruh terhadap manajemen laba. Hasil penelitian ini didukung oleh penelitian yang dilakukan Asitalia dan Trisnawati (2017), Firnanti (2017), serta Guna dan Herawaty (2010). Hipotesis yang diajukan adalah:

$\mathrm{H}_{8}$ Dewan Komisaris Independen berpengaruh terhadap manajemen laba.

\section{Umur Perusahaan}

Semakin lama perusahaan berdiri maka akan lebih banyak menghadapi tantangan dalam hal bisnis yang akan membuat perusahaan tersebut mempunyai strategi untuk mampu bertahan. Oleh 
karenanya diharapkan memiliki tingkat manajemen laba yang lebih kecil dibandingkan dengan perusahaan yang baru berdiri.

Menurut Susanto, Pradipta, dan Cecilia (2019), serta Agustia dan Suryani (2018) umur perusahaan berpengaruh positif terhadap manajemen laba yang menunjukkan semakin lama umur perusahaan semakin banyak kesempatan perusahaan melakukan manajemen laba. Perusahaan yang telah lama berdiri mempunyai pengalaman dalam mengelola perusahaan dan dapat membuat rancangan yang memajukan perusahaan dengan meningkatkan laba perusahaan sehingga dapat bersaing dengan perusahaan yang baru berdiri maupun sudah lama berdiri. Sedangkan Yunietha dan Palupi (2017) menyatakan umur perusahaan tidak berpengaruh terhadap manajemen laba. Hal ini menunjukkan bahwa perusahaan yang baru berdiri maupun sudah lama berdiri tidak mempengaruhi pelaporan pelaporan laba positif dalam pelaporan kerugian perusahaan. Hipotesis yang diajukan adalah:

$\mathrm{H}_{9}$ Umur perusahaan berpengaruh terhadap manajemen laba.

\section{METODE PENELITIAN}

Populasi dalam penelitian ini adalah perusahaan manufaktur yang konsisten terdaftar di Bursa Efek Indonesia (BEI) selama periode tahun 2015 sampai dengan 2018. Berdasarkan kriteria sampel dalam penelitian ini, maka diperoleh 71 perusahaan manufaktur yang dijadikan sampel dengan prosedur pemilihan sample sebagai berikut:

Tabel 1 Prosedur Pemilihan Sample

\begin{tabular}{|c|c|c|}
\hline Kriteria Sampel & Perusahaan & Data \\
\hline $\begin{array}{l}\text { Perusahaan manufaktur yang terdaftar di Bursa Efek } \\
\text { Indonesia tahun } 2015 \text { sampai dengan } 2018 \text {. }\end{array}$ & 133 & 399 \\
\hline $\begin{array}{l}\text { Perusahaan manufaktur yang laporan keuangannya tidak } \\
\text { berakhir pada tanggal } 31 \text { Desember dari tahun } 2015 \\
\text { sampai dengan } 2018 \text {. }\end{array}$ & (3) & (9) \\
\hline $\begin{array}{l}\text { Perusahaan manufaktur yang tidak konsisten } \\
\text { menggunakan mata uang rupiah dalam penyajian laporan } \\
\text { keuangan dari tahun } 2015 \text { sampai dengan } 2018 \text {. }\end{array}$ & (26) & (78) \\
\hline $\begin{array}{l}\text { Perusahaan manufaktur yang tidak konsisten } \\
\text { menghasilkan laba dari tahun } 2016 \text { sampai dengan } 2018 .\end{array}$ & (33) & (99) \\
\hline Data Oultier & & (1) \\
\hline Jumlah & 71 & 212 \\
\hline
\end{tabular}

Pengukuran manajemen laba menggunakan metode modified jones model dalam jurnal Dechow et al. (1995), untuk menghitung nilai discretionary accruals dilakukan dengan rumus berikut:

DAit $=$ TAit - NDAit

Keterangan :

TAi, $\mathrm{t}=\mathrm{Nli}, \mathrm{t}-\mathrm{OCFi}, \mathrm{t}$
Non discretionary accruals (NDA) :

NDAit $=\beta 1(1 /$ Ait-1) $+\beta 2(\triangle$ REVit $/$ Ait-1 $\triangle$ RECit/ Ait-1) + $\beta 3$ (PPEit / Ait-1)

Discretionary accruals (DA) :

DAit $=[$ TAit/Ait-1 $]-[\beta 1(1 /$ Ait-1 $)+\beta 2$

$((\Delta$ REVit $-\triangle$ RECit $) /$ Ait- 1$)+$

$\beta 3$ (PPEit / Ait-1)]

OCFi,t = Net operating cash flow tahun-t 
TA it= Total Akrual untuk perusahaan i pada tahun-t

NDAit= Non discretionary accruals

Ait=Total aset untuk perusahaan $\mathrm{i}$ tahun $\mathrm{t}-1$

$\Delta$ REVit $=$ Perubahan operating revenue perusahaan i pada tahun-t

$\triangle$ RECit $=$ Perubahan receivable untuk perusahaan i pada tahun-t

PPEit= Property, Plant, Equipment perusahaan i pada tahun-t

$\beta 1-\beta 3=$ Regression parameters

Ukuran kantor akuntan publik merupakan salah satu alat ukur untuk mengetahui kualitas audit yang akan dihasilkan oleh seorang auditor. Ukuran kantor akuntan publik dalam penelitian ini dihitung dengan skala nominal menggunakan variabel dummy sesuai dengan penelitian Ahmad et al. (2016), nilai 1 untuk perusahaan yang diaudit oleh KAP big four, nilai 0 untuk Perusahaan yang diaudit oleh KAP non-big four.

Spesialisasi auditor merupakan salah satu alat ukur untuk mengetahui kualitas audit yang dihasilkan auditor. Spesialisasi auditor diproksikan dengan skala nominal menggunakan variabel dummy sesuai dengan penelitian Christiani and Nugrahanti (2014) nilai 1 untuk Perusahaan diaudit oleh spesialisasi industri auditor, nilai 0 Perusahaan tidak diaudit oleh spesialisasi indutri auditor.

Ukuran perusahaan merupakan salah satu skala yang digunakan untuk mengklasifikasikan perusahaan. Besar kecilnya perusahaan dapat dilihat dari total aset, jumlah penjualan, rata-rata penjualan nilai saham atas perusahaan. Dalam penelitian ini, ukuran perusahaan diukur menggunakan Ln Total Assets (Ahmad et al. 2016).

Aliran kas operasi merupakan aliran kas yang berasal dari penerimaan dan pengeluaran kas yang diperoleh dan digunakan untuk kegiatan operasional perusahaan Dalam penelitian ini, aliran kas operasi diukur dengan menggunakan skala rasio dengan rumus sebagai berikut (Ahmad et al. 2016):

$$
\text { OCF }=\frac{\text { Operating cash flow }}{\text { Total Asset }}
$$

Leverage menggambarkan penggunaan sumber dana dari kegiatan operasi perusahaan dan menunjukkan risiko yang mungkin dihadapi perusahaan. Dalam penelitian ini, leverage diukur dengan skala rasio menggunakan rumus sebagai berikut (Ahmad et al. 2016) :

$$
\text { LEV }=\frac{\text { Total Debt }}{\text { Total Asset }}
$$

Return on asset berfungsi sebagai alat ukur untuk melihat efektivitas perusahaan dalam menghasilkan laba menggunakan aset milik perusahaan. Return on asset diukur dengan skala rasio menggunakan rumus sebagai berikut (Yuliana dan Trisnawati, 2015) :

Return on asset $=$

Earnings before interest and tax

Total asset

Market to book value ratio memberikan penilaian tentang bagaimana investor melihat kinerja perusahaan (Gitman dan Zutter, 2015). Dalam penelitian ini, market to book value ratio diukur dengan skala rasio menggunakan rumus sebagai berikut (Yuliana dan Trisnawati 2015):

Market to book value ratio $=$ market value of common equity book value of common equity 
Dalam penelitian ini, dewan komisaris independen diukur dengan skala rasio menggunakan rumus sebagai berikut (Wimelda and Chandra, 2018) :

Dewan komisaris independen $=$

Jumlah komisaris independen

Total anggota komisaris

Menurut Zen dan Herman (2007) dalam Agustia dan Suryani (2018) Umur perusahaan adalah jumlah tahun sejak perusahaan berdiri sampai perusahaan tersebut sanggup menjalankan operasinya. Semakin lama Perusahaan berdiri akan meningkatkan kepercayaan investor dibandingkan perusahaan yang baru berdiri, hal ini karena diasumsikan laba yang lebih tinggi akan dihasilkan oleh perusahaan yang telah lama berdiri dibandingkan perusahaan yang baru berdiri. AGE = Tahun berjalan Tahun terbentuknya perusahaan

\section{HASIL PENELITIAN}

Statistik deskriptif penelitian adalah sebagai berikut:

Tabel 2 Statistik Deskriptif

\begin{tabular}{lrrrr}
\hline Varaibel & \multicolumn{1}{c}{ Minimum } & \multicolumn{1}{c}{ Maximum } & \multicolumn{1}{l}{ Mean } & \multicolumn{1}{c}{ Std. Deviation } \\
\hline EM & $-0,18209$ & 0,25452 & $-0,00236$ & 0,06058 \\
UAD & 0 & 1 & 0,43 & 0,496 \\
SA & 0 & 1 & 0,22 & 0,416 \\
SIZE & 25,64046 & 33,47373 & 28,61880 & 1,54743 \\
OCF & $-0,11184$ & 0,54877 & 0,09405 & 0,09767 \\
LEV & 0,07689 & 0,84478 & 0,39509 & 0,17943 \\
ROA & 0,01201 & 0,71920 & 0,12371 & 0,10729 \\
MBV & 0,07011 & 82,44443 & 3,36984 & 8,38955 \\
DKI & 0,20000 & 0,66667 & 0,40062 & 0,09640 \\
AGE & 7 & 89 & 40,11 & 15,419 \\
\hline SUm
\end{tabular}

Sumber : Hasil pengolahan data SPSS 25

Tabel 3 Hasil Uji $\mathbf{t}$

\begin{tabular}{ccc}
\hline Variabel & B & sig \\
\hline (Constant) & $-0,127$ & 0,000 \\
UAD & 0,007 & 0,161 \\
SA & 0,0003 & 0,956 \\
SIZE & 0,005 & 0,000 \\
OCF & $-1,087$ & 0,000 \\
LEV & $-0,026$ & 0,003 \\
ROA & 0,789 & 0,000 \\
MBV & 0,0002 & 0,553 \\
DKI & $-0,014$ & 0,368 \\
AGE & 0,0002 & 0,165
\end{tabular}

Sumber : Hasil pengolahan Data SPSS 25 
Hasil uji t ukuran kantor akuntan publik pada tabel 3 menunjukkan Nilai signifikansi sebesar 0,161 yang lebih besar dari 0,05 sehingga menunjukkan tidak adanya pengaruh ukuran kantor akuntan publik terhadap manajemen laba. Hasil ini menunjukkan bahwa $\mathrm{H}_{1}$ tidak diterima, artinya siapapun yang mengaudit perusahaan kemungkinan melakukan manajemen laba tetap terjadi. Hasil penelitian ini konsisten dengan penelitian yang dilakukan Napitupulu (2012), Rachmawati Dan Fuad (2013) serta Yuliana dan Trisnawati, (2015). Namun tidak konsisten dengan penelitian yang dilakukan Gerayli et al. (2011), Amijaya dan Prastiwi (2013) serta Ahmad et al. (2016).

Spesialisasi auditor memiliki nilai signifikansi sebesar 0,956 lebih besar dari 0,05 artinya tidak adanya pengaruh spesialisasi auditor terhadap manajemen laba. Hasil ini menunjukkan bahwa $\mathrm{H}_{2}$ tidak diterima, artinya kemampuan auditor atau spesialisasi industri seorang auditor tidak menjamin suatu perusahaan melakukan manajemen laba atau tidak. Hasil penelitian ini konsisten dengan penelitian yang dilakukan Yuliana dan Trisnawati (2015). Namun tidak konsisten dengan penelitian yang dilakukan Gerayli et al. (2011), Ahmad et al. (2016) dan Kurniawansyah (2016).

Ukuran perusahaan memiliki nilai signifikansi sebesar 0,000 . Nilai signifikansi lebih kecil dari 0,05 menunjukkan adanya pengaruh positif ukuran perusahaan terhadap manajemen laba. Hasil ini menunjukkan bahwa $\mathrm{H}_{3}$ diterima, artinya semakin besar ukuran perusahaan maka perusahaan akan mempertahankan nama baiknya dengan melakukan manajemen laba. Hasil penelitian ini konsisten dengan penelitian Amijaya dan prastiwi (2013), Yuliana dan Trisnawati (2015), Kurniawansyah (2016), dan Susanto (2016). Namun tidak konsisten dengan penelitian yang dilakukan Rachmawati dan Fuad, (2013), Christiani dan Nugrahanti (2014) serta Yunietha dan Palupi (2017).

Aliran kas operasi memiliki nilai signifikansi sebesar 0,000 . Nilai signifikansi lebih kecil dari 0,05 menunjukkan adanya pengaruh negatif aliran kas operasi terhadap manajemen laba. Hasil ini menunjukkan bahwa $\mathrm{H}_{4}$ diterima. Hal ini menunjukkan perusahaan dengan aliran kas operasi yang kecil cenderung akan melakukan manajemen laba untuk menunjukkan kinerja perusahaan yang baik. Hasil penelitian ini konsisten dengan penelitian Yuliana dan Trisnawati (2015), Rachmawati dan Fuad, (2013) serta Christiani dan Nugrahanti (2014). Namun tidak konsisten dengan penelitian yang dilakukan Ahmad et al. (2016), Gerayli et al. (2011) serta Amijaya dan Prastiwi (2013).

Leverage memiliki nilai signifikansi sebesar 0,003 . Nilai signifikansi lebih kecil dari 0,05 menunjukkan adanya pengaruh negatif leverage terhadap manajemen laba. Hasil ini menunjukkan bahwa $\mathrm{H}_{5}$ diterima. $\mathrm{Hal}$ ini menunjukkan bahwa apabila leverage dalam suatu perusahaan tinggi maka praktik manajemen laba dalam perusahaan tersebut rendah. Hasil penelitian ini konsisten dengan penelitian Aygun et al. (2014), Yuliana dan Trisnawati (2015), dan Susanto (2013). Namun tidak konsisten dengan penelitian yang dilakukan Gerayli et al. (2011), Agustia (2013) dan Ahmad et al. (2016).

Return on asset memiliki nilai signifikansi sebesar 0,000 . Nilai signifikansi lebih kecil dari 0,05 menunjukkan adanya pengaruh positif return on asset terhadap manajemen laba. Hasil ini menunjukkan bahwa $\mathrm{H}_{6}$ diterima. Hasil penelitian ini konsisten dengan penelitian Susanto dan Yangrico (2020), Susanto, Pradipta, dan Cecilia, (2019), Yuliana dan Trisnawati (2015), Amertha (2013), dan Aygun et al. (2014). Namun tidak konsisten 
dengan penelitian yang dilakukan Nurdiniah dan Herlina (2015), serta Chandra dan Djashan (2018).

Market to book value ratio memiliki nilai signifikansi sebesar 0,553 . Nilai signifikansi lebih besar dari 0,05 menunjukkan tidak adanya pengaruh market to book value ratio terhadap manajemen laba. Hasil ini menunjukkan bahwa $\mathrm{H}_{7}$ tidak diterima. Hasil ini menunjukkan harga saham suatu perusahaan tidak memiliki pengaruh terhadap tindakan manajemen laba. Hasil penelitian ini konsisten dengan penelitian Yuliana dan Trisnawati (2015). Namun tidak konsisten dengan penelitian yang dilakukan Almalita (2017), dan Christiani dan Nugrahanti (2014).

Dewan komisaris independen memiliki nilai signifikansi sebesar 0,368. Nilai signifikansi lebih besar dari 0,05 menunjukkan tidak adanya pengaruh dewan komisaris independen terhadap manajemen laba. Hasil ini menunjukkan bahwa $\mathrm{H}_{8}$ tidak diterima. Hasil penelitian ini konsisten dengan penelitian Wimelda dan Chandra (2018), serta Asitalia dan Trisnawati (2017). Namun tidak konsisten dengan penelitian yang dilakukan oleh Arifin dan Destriana (2016), Susanto (2016) serta Herlambang dan Darsono (2015).

Umur Perusahaan memiliki nilai signifikansi sebesar 0,165 . Nilai signifikansi lebih besar dari 0,05 menunjukkan tidak adanya pengaruh umur perusahaan terhadap manajemen laba. Hasil ini menunjukkan bahwa $\mathrm{H}_{9}$ tidak diterima artinya perusahaan yang baru berdiri maupun sudah lama berdiri tidak mempengaruhi terjadinya manajemen laba. Hasil penelitian ini konsisten dengan penelitian Yunietha dan Palupi (2017), Savitri (2014) dan
Zen dan Herman (2007). Tetapi tidak konsisten dengan penelitian Agustia dan Suryani (2018).

\section{PENUTUP}

Ukuran perusahaan, aliran kas operasi, leverage, dan return on asset berpengaruh terhadap manajemen laba. Sedangkan ukuran kantor akuntan public, spesialisasi auditor, market to book value ratio, dewan komisaris independen, dan umur perusahaan tidak berpengaruh terhadap manajemen laba. Semakin besar ukuran perusahaan maka perusahaan akan mempertahankan nama baiknya dengan melakukan manajemen laba untuk mempertahankan posisinya pada keadaan tertentu.

Keterbatasan yang ada dalam penelitian ini, yaitu Periode penelitian dalam penelitian ini adalah 3 tahun, yaitu tahun 2016 sampai dengan 2018 dan variabel independen yang digunakan terdiri dari 9 variabel, dimana terdapat 5 variabel yang tidak memiliki pengaruh terhadap variabel dependen yang meliputi ukuran kantor akuntan publik, spesialisasi auditor, market to book value ratio, dewan komisaris independen dan umur perusahaan.

Berdasarkan keterbatasan yang ada dalam penelitian ini, maka peneliti memberikan rekomendasi untuk penelitian selanjutnya adalah Penelitian selanjutnya dapat memperpanjang periode penelitian dan penelitian selanjutnya dapat menambah variabel lain yang diharapkan dapat berpengaruh signifikan terhadap manajemen laba, seperti variabel arus kas bebas, kepemilikan manajerial, kepemilikan institusional dan komite audit. 


\section{REFERENCES:}

Abbadi, Sinan S, Qutaiba F,Hijazi \& Ayat S. Al-Rahahleh. 2016. Corporate Governance Quality and Earnings Management: Evidence from Jordan. Australasian Accounting, Business and Finance Journal, 10(2).

Agustia, Dian. 2013. Pengaruh Faktor Good Corporate Governance, Free Cash Flow, dan Leverage Terhadap Manajemen Laba. Jurnal Akuntansi dan Keuangan, 15(1), $27-42$.

Ahmad, Lukman., Edi Suhara \& Yusri llyas. 2016.The Effect of Audit Quality on Earning Management within Manufacturing Companies Listed on Indonesian Stock Exchange. Research Journal of Finance and Accounting, 7(8).

Alexander, Nico \& Hengky. 2017. Factors Affecting Earninga Management in the Indonesian Stock Exchange. J. Bank. Fin. Review, 2(2), 8-14.

Almalita, Yuliani. 2017. Pengaruh Corporate Governance dan Faktor Lainnya Terhadap Manajemen Laba. Jurnal Bisnis dan Akuntansi, 19(2), 183-194.

Amertha, Indra Satya Prasavita. 2013. Pengaruh Return on Asset Pada Praktik Manajemen Laba dengan Moderasi Corporate Governance. E-Jurnal Akuntansi Universitas Udayana, 4(2).

Amijaya, Muhammad Dody, \& Andri Prastiwi. 2013. Pengaruh Kualitas Audit Terhadap Manajemen Laba. Diponegoro Journal of Accounting, 2(3), 1-13.

Arifin, Lavenia \& Nicken Destriana. 2016. Pengaruh Firm Size, Corporate Governance, Karakteristik Perusahaan Terhadap Manajemen Laba. Jurnal Bisnis dan Akuntansi, 18(1), 84-93.

Asitalia, Fioren \& Ita Trisnawati. 2017. Pengaruh Good Corporate Governance dan Leverage terhadap Manajemen Laba. Jurnal Bisnis dan Akuntansi, 19(1a), 109-119.

Atiqah, Miratul \& Agus Purwanto. 2011. Pengaruh Risiko Litigasi Terhadap Manajemen Laba dengan Kualitas Audit Sebagai Variabel Moderating. Jurnal Akuntansi \& Auditing,7(2), 203-212.

Aygun, Mehmed, Suleyman Ic dan Mustafa Sayim. 2014. The Effect of Corporate Ownership Structure and Board Size on Earnings Management: Evidence from Turkey. International Journal of Business and Management, 9(12), 123-132.

Chandra, Stefani Magdalena \& Indra Arifin Djashan. 2018. Pengaruh Leverage dan Faktor lainnya terhadap Manajemen Laba pada Perusahaan Non Keuangan. Jurnal Bisnis dan Akuntansi, 20(1), 13-20.

Christiani, Ingrid \& Widi Nugrahanti. 2014. Pengaruh Kualitas Audit Terhadap Manajemen Laba. Jurnal Akuntansi dan Keuangan Indonesia, 16(1), 52-56.

Dechow, Patricia M., Richard G. Sloan \& Amy P. Sweeney. 1995. Detecting Earnings Management. The Accounting Review, 70(2), 193-225.

Eisenhardt, Kathleen M. 1989. Agency Theory: An Assessment and review. The Academy of Management Review, Vol.14, No. 1, 57-74.

Fahmi, Irham. 2014. Manajemen Keuangan Perusahaan dan Pasar Modal. Edisi Pertama. Jakarta: Penerbit Mitra Wacana Media.

Firnanti, Friska. Pengaruh Corporate Governance, dan Faktor-Faktor lainnya terhadap Manajemen Laba. Jurnal Bisnis dan Akuntansi. 19(1), 66-80.

Gerayli, Mahdi Safari., Abolfazl Momeni Yanesari dan Ali Reza Ma'atoofi. 2011. Impact of Audit Quality on Earnings Management : Evidence From Iran. International Research Journal of Finance and Economics, 66.

Gitman, Lawrence J. Dan Chad J. Zutter. 2015. Principal of Managerial Finance. 14th Edition. United States of America: Pearson Education Limited.

Guna, Welvin I \& Arleen Herawaty. Pengaruh Mekanisme Good Corporate Governance, Independensi Auditor, Kualitas Audit dan Faktor lainnya terhadap Manajemen Laba. Jurnal Bisnis dan Akuntansi, 12(1), 53 - 68.

Handayani, Sri \& Rachadi Agustono Dwi. 2009. Pengaruh Ukuran Perusahaan Terhadap Manajemen Laba. Jurnal Bisnis dan Akuntansi, 11(1), 33-56.

Healy, P. M., \& Wahlen, J. (1999). A Review of the Earnings Management Literature and its Implications for Standard Setting.

Herlambang, Setyarso \& Darsono. 2015. Pengaruh Good Corporate Governance dan Ukuran Perusahaan Terhadap Manajemen Laba. Diponegoro Journal of Accounting, 4(3), 1-11. 
Jensen, Michael C \& Meckling W.H.1976. Theory of The Firm:Managerial Behavior, Agency Cost and Ownership Structure. Journal of Financial Economics 3, 305-360.

Kurniawansyah, Deddy. 2016. Pengaruh Audit Tenure, Ukuran Auditor, Spesialisasi Audit dan Audit Capacity Stress Terhadap Manajemen Laba. Jurnal Riset Akuntansi dan Bisnis Airlangga, 1(1), 1-25.

Minanari \& Ratu Andhini Kusumaningrat. 2017. Effect of Tax Deferred Charges, Leverage and Size of Management Company Earnings (Empirical Study at Company Jakarta Islamic Index (JII) Listed in Indonesia Stock Exhange Period 2012-2015). Research Journal of Finance and Accounting, 8(12).

Mohammad, Wan Masliza Wan, Shaista Wasiuzzaman \& Nik Mohamad Zaki Nik Salleh. 2016. Board and Audit Committee Effectiveness, Ethnic Diversification and Earnings Management: A Study of the Malaysian Manufacturing Sector. Emerald Group Publishing Limited, 16(4),.726-746.

Napitupulu, Rintar H.E. 2012. Faktor-Faktor yang mempengaruhi Manajemen Laba pada Perusahaan Manufaktur yang Terdaftar di Bursa Efek Indonesia. Jurnal Bisnis dan Akuntansi, 14(2a), 61-78.

Ngamchom, Wasukarn. 2015. Impact of Board Effectiveness and Shareholders Structure on Earnings Management in Thailand. Review of Integrative Business \& Economics Research, 4(2).

Nurdiniah, Dade \& Linda herlina. 2015. Analysis of Factors Affecting the Motivation of Earnings Management in Manufacturing Listed in Indonesia Stock Exchange. Research Journal of Finance and Accounting, 6(3).

Pradhana, Stephanus Wisnu \& Felizia Arni Rudiawarni. 2013. Pengaruh Kualitas Audit Terhadap Earnings Manajemen Pada Perusahaan Sektor Manufaktur yang Go Public di BEl. Jurnal IImiah Mahasiswa Universitas Surabaya, 2(1).

Rachmawati, Yulia \& Fuad. 2013. Pengaruh Kualitas Auditor Terhadap Manajemen Laba. Diponegoro Journal of Accounting, 2(3), 1-9.

Scott, William Robert. 2015. Financial Accounting Theory. $7^{\text {th }}$ Edition. Un ited States: Pearson Canada Inc.

Sibarani, Thomas Junior, Nur Hidayat \& Surtikanti. 2015. Analisis Pengaruh Beban Pajak Tangguhan, Discretionary Accruals dan Arus Kas Operasi terhadap Manajemen Laba. Jurnal Riset Akuntabsi dan Perpajakan, 2(1), 19-31.

Susanto, Y.K. 2013. The Effect of Corporate Governance Mechanism on Earning Management Practice (Case Study on Indonesia Manufacturing Study). Jurnal Bisnis dan Akuntansi, 15(2), 157-167.

Susanto, Y.K. 2016. The Effect of Audit Committees and Corporate Governance on Earnings Management: Evidence from Indonesia Manufacturing Industry. International Journal of Business, Economics and Law, 10(1), 32-37.

Susanto, Y.K., Pradipta, A., \& Cecilia, E. 2019. Earnings Management: ESOP and Corporate Governance. Academy of Accounting and Financial Studies Journal, 23(Spesial Issue 1).

Susanto Y.K., Pirzada K., \& Adrianne S. 2019, Is tax aggressiveness an indicator of earnings management? Polish Journal of Management Studies, 20(2), 516-527.

Susanto, Yulius Kurnia, \& Yangrico, Kevin Edrick. 2020. Earnings Management: Evaluation of Audit Committee Activity in Indonesia. Substansi: Sumber Artikel Akuntansi, Auditing, dan Keuangan Vokasi, 4(1), 64-77.

Wimelda, Linda \& Agustina Chandra. 2018 Opportunistic Behavior, External Monitoring Mechanisms, Corporate Governance, and Earnings Management. Accounting and Finance Review. Acc. Fin. Review, 3(1), 49-57.

Yuliana, Agustin \& Ita Trisnawati. 2015. Pengaruh Auditor dan Rasio Keuangan Terhadap Manajemen Laba. Jurnal Bisnis dan Akuntansi, 17(1), 33-45

Yunietha \& Agustin Palupi. 2017. Pengaruh Corporate Governance dan Faktor Lainnya terhadap Manajemen Laba Perusahaan Publik Non Keuangan. Jurnal Bisnis dan Akuntansi, 19(1a), 292-303. 
